\begin{abstract}
Iranica
Abstracta Iranica Revue bibliographique pour le domaine irano-aryen

Volume 32-33 | 2013

Comptes rendus des publications de 2009-2010
\end{abstract}

\title{
André Lemaire. Deux cruches avec inscriptions araméennes
}

Astrid Nunn

\section{(2) OpenEdition}

1 Journals

Édition électronique

URL : http://journals.openedition.org/abstractairanica/40353

DOI : 10.4000/abstractairanica.40353

ISSN : 1961-960X

\section{Éditeur :}

CNRS (UMR 7528 Mondes iraniens et indiens), Éditions de l'IFRI

\section{Édition imprimée}

Date de publication : 1 décembre 2013

ISSN : 0240-8910

\section{Référence électronique}

Astrid Nunn, "André Lemaire. Deux cruches avec inscriptions araméennes », Abstracta Iranica [En ligne], Volume 32-33 | 2013, document 91, mis en ligne le 01 juillet 2016, consulté le 05 octobre 2020. URL: http://journals.openedition.org/abstractairanica/40353; DOI : https://doi.org/10.4000/ abstractairanica.40353

Ce document a été généré automatiquement le 5 octobre 2020.

Tous droits réservés 


\title{
André Lemaire. Deux cruches avec inscriptions araméennes
}

\author{
Astrid Nunn
}

\section{RÉFÉRENCE}

André Lemaire. « Deux cruches avec inscriptions araméennes ». Trans. 38, 2009, p. 31-34.

Deux cruches à huile odorante apparues sur le marché des antiquités portent deux courtes inscriptions araméennes. Sans doute proviennent-elles du Levant. Les deux inscriptions consistent en le nom du propriétaire et peuvent être datées du $\mathrm{V}^{\mathrm{e}} \mathrm{s}$. av. J.C.

\section{AUTEURS}

\section{ASTRID NUNN}

Université de Munich 